Cite this: Food Funct., 2014, 5, 1113

\title{
A standardised static in vitro digestion method suitable for food - an international consensus $\dagger$
}

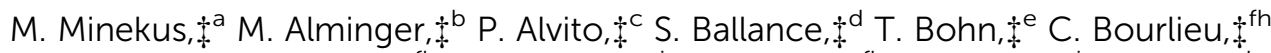

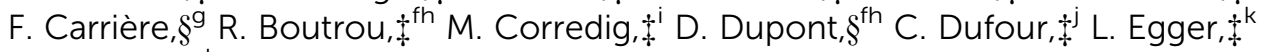 \\ M. Golding, $\|^{l}$ S. Karakaya, $\ddagger^{m}$ B. Kirkhus, $\S^{n}$ S. Le Feunteun, $\ddagger^{0}$ U. Lesmes, $\ddagger^{p}$ \\ A. Macierzanka, $\neq^{\mathrm{a}}$ A. Mackie, $\$^{\mathrm{r}}$ S. Marze, $\S^{\mathrm{s}}$ D. J. McClements, $\|^{\mathrm{t}} \mathrm{O}$. Ménard, $\neq^{\text {fh }}$

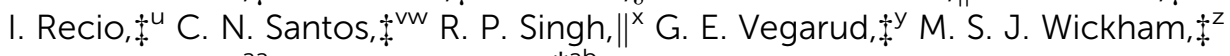 \\ W. Weitschies: $\AA^{\text {aa }}$ and A. Brodkorb $t^{\star a b}$
}

Simulated gastro-intestinal digestion is widely employed in many fields of food and nutritional sciences, as conducting human trials are often costly, resource intensive, and ethically disputable. As a consequence, in vitro alternatives that determine endpoints such as the bioaccessibility of nutrients and non-nutrients or the digestibility of macronutrients (e.g. lipids, proteins and carbohydrates) are used for screening and building new hypotheses. Various digestion models have been proposed, often impeding the possibility to compare results across research teams. For example, a large variety of enzymes from different sources such as of porcine, rabbit or human origin have been used, differing in their activity and characterization. Differences in $\mathrm{pH}$, mineral type, ionic strength and digestion time, which alter enzyme activity and other phenomena, may also considerably alter results. Other parameters such as the presence of phospholipids, individual enzymes such as gastric lipase and digestive emulsifiers vs. their mixtures (e.g. pancreatin and bile salts), and the ratio of food bolus to digestive fluids, have also been discussed at length. In the present consensus paper, within the COST Infogest network, we propose a general standardised and practical static digestion method based on physiologically relevant conditions that can be applied for various endpoints, which may be amended to accommodate further specific requirements. A frameset of parameters including the oral, gastric and small

Received 23rd December 2013 Accepted 5th April 2014

DOI: $10.1039 / c 3 f 060702 j$

www.rsc.org/foodfunction intestinal digestion are outlined and their relevance discussed in relation to available in vivo data and enzymes. This consensus paper will give a detailed protocol and a line-by-line, guidance, recommendations and justifications but also limitation of the proposed model. This harmonised static, in vitro digestion method for food should aid the production of more comparable data in the future.
${ }^{a}$ TNO, PO BOX 360, 3700AJ Zeist, The Netherlands. E-mail: Mans.Minekus@tno.nl ${ }^{b}$ Chalmers University of Technology, Department of Chemical and Biological Engineering, SE-412 96 Gothenburg, Sweden. E-mail: Marie.Alminger@chalmers.se 'National Institute of Health Doutor Ricardo Jorge, I.P., Food and Nutrition Department, Av. Padre Cruz, 1649-016 Lisboa, Portugal. E-mail: Paula.Alvito@ insa.min-saude.pt

${ }^{d}$ Nofima AS, Osloveien 1, NO-1430 Ås, Norway. E-mail: Simon.Ballance@nofima.no ${ }^{e}$ Centre de Recherche Public - Gabriel Lippmann, 41 rue du Brill, 4422 Belvaux, Luxembourg. E-mail: Bohn@lippmann.lu

${ }^{f} I N R A$, UMR1253 Science et Technologie du Lait et de l'Oeuf, F-35042 Rennes, France.E-mail: Claire.Bourlieu@rennes.inra.fr; Didier.Dupont@rennes.inra.fr ${ }^{8}$ CNRS-Aix Marseille University, UMR7282, 31 Chemin Joseph-Aiguier, F-13402 Marseilles Cedex 20, France. E-mail: carriere@imm.cnrs.fr

${ }^{h}$ AGROCAMPUS OUEST, UMR1253 Science et Technologie du Lait et de l'Oeuf, F-35042 Rennes, France.E-mail: Rachel.Boutrou@rennes.inra.fr; olivia.menard@ rennes.inra.fr

${ }^{i}$ University of Guelph, Department of Food Science, Ontario N1G 2W1, Canada. E-mail: Mcorredi@uoguelph.ca

iINRA, UMR SQPOV, Domaine Saint-Paul - Site Agroparc 84914, Avignon Cedex 9, France.E-mail: Claire.dufour@avignon.inra.fr

${ }^{k}$ Agroscope Liebefeld-Posieux Research Station ALP, Schwarzenburgstrasse 161, CH-3003 Berne, Switzerland. E-mail: Carlotte.Eger@agroscope.admin.ch
'Institute of Food, Nutrition and Human Health, Riddet Institute, Massey University, Private Bag 11 222, Palmerston North 4442, New Zealand. E-mail: M.Golding@ massey.ac.nz

${ }^{m}$ Ege University, Engineering Faculty Department of Food Engineering, 35100 Izmir, Turkey.E-mail: Sibel.Karakaya@ege.edu.tr

${ }^{n}$ Nofima, Osloveien 1, NO-1430 Ås, Norway. E-mail: Bente.Kirkhus@nofima.no ${ }^{\circ} I N R A$ AgroParisTech, UMR GMPA 782, 78850 Thiverval grignon, France. E-mail: Steven.Le-Feunteun@grignon.inra.fr

${ }^{p}$ Department of Biotechnology and Food Engineering, Technion - Israel Institute of Technology, Haifa 3200o, Israel.E-mail: lesmesu@tx.technion.ac.il

${ }^{9}$ Institute of Food Research, Norwich Research Park, Colney, NR4 7UA Norwich, UK. E-mail: Adam.Macierzanka@ifr.ac.uk

$\dagger$ Electronic supplementary information (ESI) available. See DOI: $10.1039 / \mathrm{c} 3 f 060702 \mathrm{j}$

$\ddagger$ These authors contributed to the definition of digestion parameters and the writing/editing of the manuscript.

$\S$ These authors contributed to the definition of digestion parameters and the revision of the manuscript.

|| These authors contributed to the manuscript by critical revision of digestion parameters and manuscript. 


\section{Introduction}

In vitro methods simulating digestion processes are widely used to study the gastro-intestinal behaviour of food or pharmaceuticals. Although human nutritional studies are still being considered the "gold standard" for addressing diet related questions, in vitro methods have the advantage of being more rapid, less expensive, less labour intensive, and do not have ethical restrictions. This allows a relatively large number of samples to be measured in parallel for screening purposes. Reproducibility, choice of controlled conditions and easy sampling at the site of interest make in vitro models very suitable for mechanistic studies and hypothesis building.

Simulated digestion methods typically include the oral, gastric and small intestinal phases, and occasionally large intestinal fermentation. These methods try to mimic physiological conditions in vivo, taking into account the presence of digestive enzymes and their concentrations, $\mathrm{pH}$, digestion time, and salt concentrations, among other factors. Some computerized sophisticated models such as the Dutch TNO gastrointestinal tract model, ${ }^{1}$ the model by the English Institute of Food Research $^{2}$ or by the French INRA ${ }^{3}$ allowing the simulation of dynamic aspects of digestion, such as transport of digested meals, variable enzyme concentrations and $\mathrm{pH}$ changes over time. However, the majority of models reported in literature are static ones, ${ }^{4}$ i.e. models with constant ratios of meal to enzymes, salt, bile acids etc. at each step of digestion.

Static models of human digestion have been used to address such diverse scientific questions as the digestibility and bioaccessibility (i.e. the amount of a compound that is released from the matrix and is considered to be available for absorption through the gut wall) of pharmaceuticals, ${ }^{5}$ mycotoxins, ${ }^{6}$ and macronutrients such as proteins, ${ }^{7,8}$ carbohydrates $^{9}$ and lipids. ${ }^{10,11}$ They have also been used to study matrix release of micronutrients such as minerals and trace elements, ${ }^{12}$ and secondary plant compounds including carotenoids ${ }^{13}$ and polyphenols. ${ }^{14,15}$ Some digestion methods are used to produce bioaccessible fractions that can be used to address further mechanistic questions, such as intestinal transport by employing Caco-2 cells. ${ }^{16}$ Although many in vitro methods are derived from earlier reported methods, there is significant variation in the use of $i n$ vitro digestion parameters between the individual models described in literature, ${ }^{17-19}$ impeding the possibility to compare results across research-groups and to deduce general findings. While altering some of these

${ }^{r}$ Institute of Food Research, Norwich, NR4 7UA Norfolk, UK. E-mail: Alan.Mackie@ ifr.ac.uk

${ }^{s}$ UR1268 Biopolymères Interactions Assemblages, INRA, F-44300, Nantes, France. E-mail: Sebastien.Marze@nantes.inra.fr

${ }^{t}$ Department of Food Science, University of Massachusetts, Chenoweth Lab., Amherst, MA01003, USA.E-mail: mcclements@foodsci.umass.edu

"Instituto de Investigación en Ciencias de la Alimentación (CIAL, CSIC-UAM), Nicolás Cabrera 9, 28049 Madrid, Spain.E-mail: i.recio@csic.es

${ }^{v}$ Instituto de Biologia Experimental e Tecnológica, Apartado 12, 2781-901 Oeiras, Portugal

${ }^{w}$ Instituto de Tecnologia Química e Biológica, Universidade Nova de Lisboa, Av. da República, EAN, 2781-901 Oeiras, Portugal.E-mail: csantos@ibet.pt parameters may have a limited impact on the matrix release or digestibility of some compounds, there could be a large impact for other ingredients. Enzyme activity is also altered by $\mathrm{pH}$ and the concentration of salts such as calcium. The applied gastric $\mathrm{pH}$ may vary greatly between the models, i.e. from $\mathrm{pH} 2^{20}$ to $\mathrm{pH}$ $4 .^{21}$ The COST action INFOGEST ${ }^{22}$ is an international network joined by more than 200 scientists from 32 countries working in the field of digestion. One aim of the network is to consolidate conditions for simulated digestion of food and find a consensus, if possible, for a digestion model. The group is aware that no conditions outlined will be suited for all underlying research questions. However, the authors of this manuscript strived to describe a "smallest common denominator", i.e. a set of conditions that are close to the physiological situation, are practical, and can be seen as a basic suggestion to address various research questions. Further amendments of these suggested conditions may be needed, for example to simulate digestion in infants or the elderly, which may differ considerably in enzyme concentration. ${ }^{23-25}$ For more accurate simulation of in vivo conditions, dynamic models should be used. In the next sections, we describe our recommendations for a standardised digestion method which is based on the current state of knowledge on in vivo digestion conditions, and employs widely available instrumentation and chemicals.

\section{Experimental - in vitro digestion protocol}

This section describes a detailed line-by-line protocol, which is also summarised in Fig. 1. Further information and justification on the choice and concentration of chemicals, inclusion or omission of certain steps are discussed in greater detail in the following section "In vitro digestion parameters - recommendation and justification".

\section{Materials}

All materials are standard analytical grade. Sodium bicarbonate $(0.5 \mathrm{M})$ should be filtered through a $0.22 \mu \mathrm{m}$ filter under vacuum. It can be stored at $2-5^{\circ} \mathrm{C}$ for approximately one month. The type of enzyme products, mostly provided by Sigma Aldrich (St Louis, Mo), is only a recommendation and similar products of comparable quality from other providers can be used. Enzyme activities are based on commonly used assays. Detailed protocols of the enzyme assays are outlined in the ESI. $\dagger \alpha-$

${ }^{x}$ Department of Biological and Agricultural Engineering, Department of Food Science and Technology, University of California, Davis, CA 95616, USA. E-mail:rpsingh@ ucdavis.edu

${ }^{y}$ Department of Chemistry, Biotechnology and Food Science, Norwegian University of Life Sciences, 1432 Aas, Norway. E-mail: Gerd.Vegarud@umb.no

${ }^{z}$ Leatherhead Food Research, Randalls Road, Leatherhead, Surrey KT22 7RY, UK. E-mail: MWickham@leatherheadfood.com

${ }^{a a}$ Ernst Moritz Arndt University of Greifswald, D-17487 Greifswald, Germany. E-mail: Werner.Weitschies@uni-greifswald.de

${ }^{a b}$ Teagasc Food Research Centre, Moorepark, Fermoy, County Cork, Ireland. E-mail: Andre.Brodkorb@teagasc.ie 


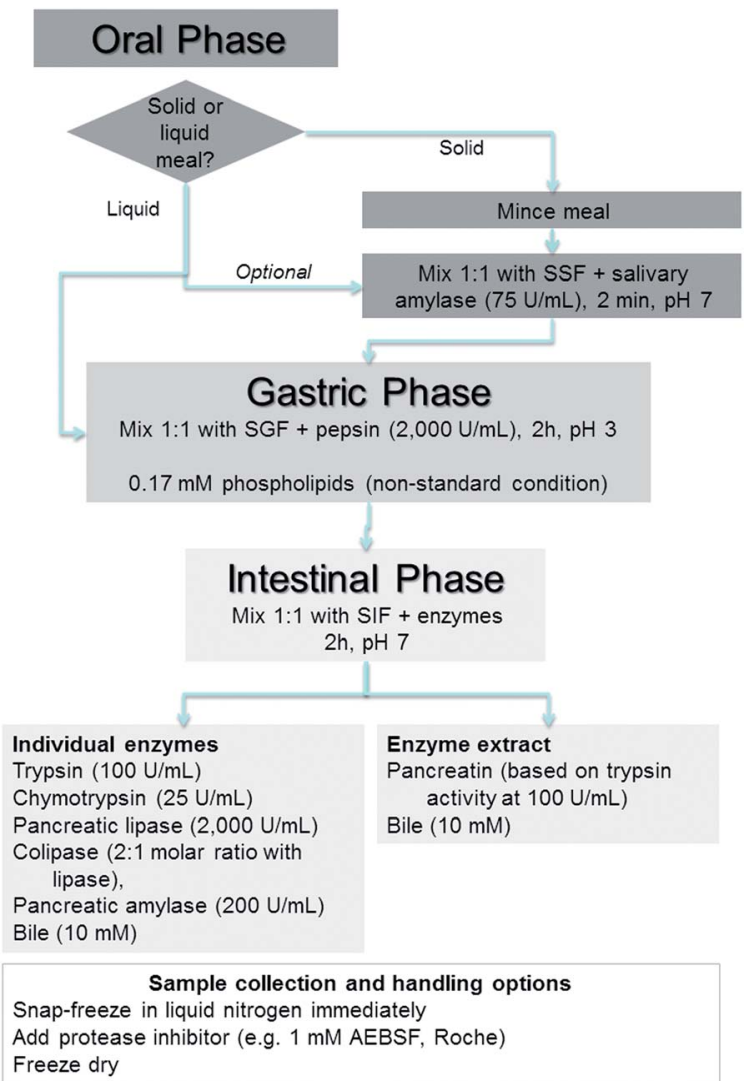

Fig. 1 Overview and flow diagram of a simulated in vitro digestion method. SSF, SGF and SIF are Simulated Salivary Fluid, Simulated Gastric Fluid and Simulated Intestinal Fluid, respectively. Enzyme activities are in units per $\mathrm{mL}$ of final digestion mixture at each corresponding digestion phase.

Amylase (EC 3.2.1.1) activity is based on soluble potato starch: one unit liberates $1.0 \mathrm{mg}$ of maltose from starch in 3 minutes at pH 6.9 at $20^{\circ}$ C. Porcine Pepsin (EC 3.4.23.1) activity is based on bovine blood haemoglobin as a substrate: one unit will produce a $\Delta A_{280}$ of 0.001 per minute at $\mathrm{pH} 2.0$ and $37^{\circ} \mathrm{C}$, measured as TCA-soluble products. Porcine trypsin (EC 3.4.21.4) activity is based on $p$-toluene-sulfonyl-L-arginine methyl ester (TAME): one unit hydrolyses $1 \mu \mathrm{mol}$ of TAME per minute at $25{ }^{\circ} \mathrm{C}, \mathrm{pH}$ 8.1. Bovine chymotrypsin (EC 3.4.21.1) activity is based on $N$ benzoyl--tyrosine ethyl ester (BTEE): one unit hydrolyses 1.0 $\mu \mathrm{mol}$ of BTEE per minute at $\mathrm{pH} 7.8$ at $25^{\circ} \mathrm{C}$. Porcine pancreatic lipase (EC 3.1.1.3) activity is based on tributyrin as a substrate: one unit liberates $1 \mu \mathrm{mol}$ butyric acid per minute at $37^{\circ} \mathrm{C}$ and at $\mathrm{pH}$ 8.0. Bile salt concentrations are measured using a commercial kit (e.g. bile acid kit, ref. 122129990 313, DiaSys Diagnostic System GmbH, Germany or similar).

\section{Simulated digestion fluids}

Simulated Salivary Fluid (SSF), Simulated Gastric Fluid (SGF) and Simulated Intestinal Fluid (SIF) are made up of the corresponding electrolyte stock solutions (Tables 1 and 2), enzymes, $\mathrm{CaCl}_{2}$ and water. The electrolyte stock solutions are $1.25 \times$ concentrated i.e. 4 parts of electrolyte stock solution +1 part water give the correct ionic composition in the simulated digestion fluids. For example $3.8 \mathrm{~mL}$ SGF electrolyte stock solution $+0.2 \mathrm{~mL}$ pepsin (made up in SGF electrolyte stock solution) $+25 \mu \mathrm{L} 0.3 \mathrm{M} \mathrm{CaCl}_{2}+975 \mu \mathrm{L}$ water $=5 \mathrm{~mL}$ SGF. Enzyme activities are in units per $\mathrm{mL}$ of final digestion mixture rather than secretion activity, unless stated otherwise.

\section{Oral phase}

Mastication of solid food is simulated by mincing an appropriate amount of food using a commercially available manual or electric mincer, such as the Eddingtons Mincer Pro (Product Code 86002, Berkshire, UK) or similar, commonly used in kitchens to mince meat. SSF electrolyte stock solution is added to create a thin paste-like consistency, similar to that of tomato paste or mustard. If necessary, the electrolyte stock solution can also be added during mincing. A final ratio of food to SSF of $50: 50(\mathrm{w} / \mathrm{v})$ is targeted. For liquid food an oral phase can be included, especially if the meal contains starch. In this case a final ratio of $50: 50(\mathrm{v} / \mathrm{v})$ is targeted. Human salivary $\alpha$-amylase (EC 3.2.1.1) is added to achieve $75 \mathrm{U} \mathrm{mL}^{-1}$ in the final mixture, followed by $\mathrm{CaCl}_{2}$ to achieve $0.75 \mathrm{mM}$ in the final mixture and the necessary amount of water to dilute the stock solution of SSF. The recommended time of contact with the enzyme is 2 minutes at $37^{\circ} \mathrm{C}$, which requires pre-warming of all reagents to $37^{\circ} \mathrm{C}$.

In a typical example: $5 \mathrm{~g}$ of solid or $5 \mathrm{~mL}$ of liquid food is mixed with $3.5 \mathrm{~mL}$ of SSF electrolyte stock solution and minced together. $0.5 \mathrm{~mL}$ salivary $\alpha$-amylase solution of $1500 \mathrm{U} \mathrm{mL}^{-1}$ made up in SSF electrolyte stock solution ( $\alpha$-amylase from human saliva Type IX-A, $1000-3000 \mathrm{U} \mathrm{mg}^{-1}$ protein, Sigma) is added followed by $25 \mu \mathrm{L}$ of $0.3 \mathrm{M} \mathrm{CaCl}_{2}$ and $975 \mu \mathrm{L}$ of water and thoroughly mixed.

\section{Gastric phase}

Liquid food can be exposed to the oral phase (optional) or directly to gastric phase, as further discussed in the main section of the manuscript. Five parts of liquid food or oral bolus, is mixed with 4 parts of SGF stock electrolyte solution to obtain a final ratio of food to SGF of $50: 50(\mathrm{v} / \mathrm{v})$ after addition of other recipients and water. Porcine pepsin (EC 3.4.23.1) is added to achieve $2000 \mathrm{U} \mathrm{mL}^{-1}$ in the final digestion mixture,

Table 1 Recommended concentrations of electrolytes in Simulated Salivary Fluid (SSF), Simulated Gastric Fluid (SGF) and Simulated Intestinal Fluid (SIF), based on human in vivo data

\begin{tabular}{|c|c|c|c|c|c|c|}
\hline \multirow[b]{2}{*}{ Constituent } & \multicolumn{2}{|l|}{ SSF } & \multicolumn{2}{|l|}{ SGF } & \multicolumn{2}{|l|}{ SIF } \\
\hline & $\mathrm{mmol} \mathrm{L}^{-1}$ & Ref. & $\mathrm{mmol} \mathrm{L}^{-1}$ & Ref. & $\mathrm{mmol} \mathrm{L}^{-1}$ & Ref. \\
\hline $\mathrm{K}^{+}$ & 18.8 & 26,27 & 7.8 & 27,28 & 7.6 & 27,28 \\
\hline $\mathrm{Na}^{+}$ & 13.6 & 27 & 72.2 & $27-29$ & 123.4 & 27,28 \\
\hline $\mathrm{Cl}^{-}$ & 19.5 & 26,27 & 70.2 & 27,28 & 55.5 & 27 \\
\hline $\mathrm{H}_{2} \mathrm{PO}_{4}^{-}$ & 3.7 & 30 & 0.9 & 27 & 0.8 & 27 \\
\hline $\mathrm{HCO}_{3}{ }^{-}, \mathrm{CO}_{3}{ }^{2-}$ & 13.7 & 27 & 25.5 & 27 & 85 & 27 \\
\hline $\mathrm{Mg}^{2+}$ & 0.15 & 26,27 & 0.1 & 27 & 0.33 & 27 \\
\hline $\mathrm{NH}_{4}{ }^{+}$ & 0.12 & 27 & 1.0 & 27 & - & \\
\hline $\mathrm{Ca}^{2+}$ & 1.5 & 26,27 & 0.15 & 27,28 & 0.6 & 27,28 \\
\hline
\end{tabular}


Table 2 Preparation of stock solutions of simulated digestion fluids. The volumes are calculated for a final volume of $500 \mathrm{~mL}$ for each simulated fluid. We recommend to make up the stock solution with distilled water to $400 \mathrm{~mL}$ instead, i.e. $1.25 \times$ concentrate, for storage at $-20^{\circ} \mathrm{C}$. In the Experimental section, these $1.25 \times$ concentrates are referred to as Simulated Salivary Fluid (SSF), Simulated Gastric Fluid (SGF) and Simulated Intestinal Fluid (SIF) electrolyte stock solutions. The addition of enzymes, bile salts, $\mathrm{Ca}^{2+}$ solution etc. and water will result in the correct electrolyte concentration in the final digestion mixture. $\mathrm{CaCl}_{2}\left(\mathrm{H}_{2} \mathrm{O}\right)_{2}$ is not added to the electrolyte stock solutions as precipitation may occur. Instead, it is added to the final mixture of simulated digestion fluid and food ${ }^{a}$

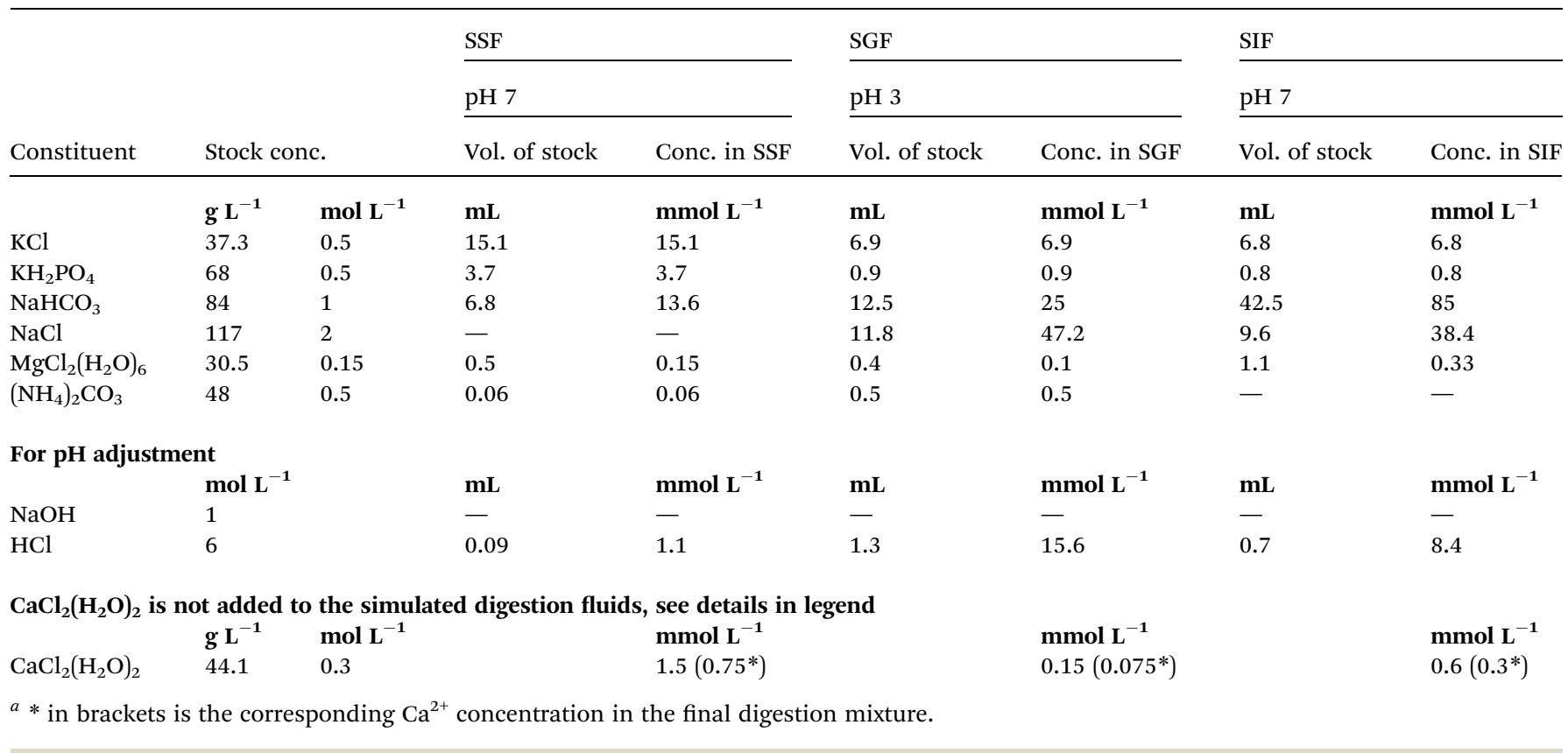

followed by $\mathrm{CaCl}_{2}$ to achieve $0.075 \mathrm{mM}$ in the final digestion mixture. $1 \mathrm{M} \mathrm{HCl}$ is added to reduce the $\mathrm{pH}$ to 3.0 ; it is recommended to determine the amount of required acid in a test experiment prior to digestion, hence acid can be added more rapidly and followed by verification of the $\mathrm{pH}$. Finally, the necessary amount of water is added to the mixture to dilute the stock solution of SGF. The use of gastric lipase is not recommended at this time because it is not commercially available (further discussed in the main text). The recommended time of digestion is 2 hours at $37^{\circ} \mathrm{C}$. The $\mathrm{pH}$ may have to be re-adjusted with $1 \mathrm{M} \mathrm{HCl}$ during digestion. Sufficient mixing during digestion is recommended, for example by placing the reaction vessel into a shaking incubator, water bath with integrated shaker or a rotator in a $37^{\circ} \mathrm{C}$ room.

In a typical example: $10 \mathrm{~mL}$ of liquid sample or oral bolus is mixed with $7.5 \mathrm{~mL}$ of SGF electrolyte stock solution, $1.6 \mathrm{~mL}$ porcine pepsin stock solution of $25000 \mathrm{U} \mathrm{mL}^{-1}$ made up in SGF electrolyte stock solution (pepsin from porcine gastric mucosa $3200-4500 \mathrm{U} \mathrm{mg}^{-1}$ protein, Sigma), $5 \mu \mathrm{L}$ of $0.3 \mathrm{M} \mathrm{CaCl}_{2}, 0.2 \mathrm{~mL}$ of $1 \mathrm{M} \mathrm{HCl}$ to reach $\mathrm{pH} 3.0$ and $0.695 \mu \mathrm{L}$ of water.

\section{Non-standard gastric condition}

In the absence of phospholipids or other low molecular weight surfactants in the tested food, it is recommended to include phospholipids ( $0.17 \mathrm{mM}$ in the final digestion mixture) in the gastric step. In this case freshly prepared SGF containing phospholipids is used instead of SGF. All other steps are as outlined above. For non-standard gastric condition using phospholipids, the following procedure is recommended. Prepare a stock solution of $50 \mathrm{mg} \mathrm{mL}{ }^{-1}$ egg lecithin (Lipid Products, Redhill UK, $500 \mathrm{mg}$ egg lecithin, approx. $63.5 \mathrm{mM}$, assuming mean $M_{\mathrm{w}}: 787 \mathrm{~g} \mathrm{~mol}^{-1}$ ) by adding 1 vial containing $500 \mu \mathrm{L}$ egg lecithin into a $10 \mathrm{~mL}$ volumetric flask wrapped in aluminium foil and filling with chloroform-methanol $(1: 1)$ solution up to the $10 \mathrm{~mL}$ mark; mix until dissolved. This can be stored for a several days at $-20{ }^{\circ} \mathrm{C}$ until required. Gastric liposomes (phospholipids) are prepared the day of usage: a $1 \mathrm{~mL}$ aliquot of the $50 \mathrm{mg} \mathrm{mL}^{-1}$ phospholipid stock solution is dried using a rotary evaporator until solvent is removed or dry remaining solvent under inert gas if no rotary evaporator is available, leaving $50 \mathrm{mg}$ of dry phospholipids. Add $5 \mathrm{~mL}$ warm SGF to reach final concentration of $10 \mathrm{mg} \mathrm{mL}^{-1}$ phospholipids in SGF. Incubate at $37^{\circ} \mathrm{C}$, shaking at $170 \mathrm{rpm}$, for $10 \mathrm{~min}$. Sonicate the solution in an ice bath until clear to the eye. Filter the sample through a $0.22 \mu \mathrm{m}$ nylon syringe filter (Thermo Scientific $^{\mathrm{TM}}$ Nalgene Syringe Filters or similar products) to remove any debris deposited by sonicator. The solution should be stored at $4{ }^{\circ} \mathrm{C}$ and used the same day.

\section{Intestinal phase}

Five parts of gastric chyme is mixed with 4 parts of SIF electrolyte stock solution to obtain a final ratio of gastric chyme to SIF of $50: 50(\mathrm{v} / \mathrm{v})$ after additions of other recipients and water. The gastric samples-chyme is mixed with SIF electrolyte stock electrolyte solution. Addition of base $(1 \mathrm{M} \mathrm{NaOH})$ will be required to neutralise the mixture to $\mathrm{pH}$ 7.0. Digestive enzymes 
can be added as either pancreatin from porcine pancreas or individual enzymes. In the case of pancreatin, proteolytic, lipolytic and amylolytic activity of the extract should be determined using the assays outlined in Enzyme assays section. The amount of pancreatin added is based on the trypsin activity (100 $\mathrm{U} \mathrm{mL}^{-1}$ in the final mixture). If the food contains high amounts of fat or the fat digestion is at the centre of the study, pancreatin concentration should be either based on the lipase activity or additional porcine pancreatic lipase and colipase should be added to achieve $2000 \mathrm{U} \mathrm{mL}^{-1}$ lipase activity in the final mixture. This is further discussed in the main section of the paper. Alternatively, individual enzymes can be added to the digestion mixture to achieve the following activities in the final mixture: porcine trypsin (EC 3.4.21.4) (100 $\mathrm{U} \mathrm{mL}^{-1}$ ), bovine chymotrypsin (EC 3.4.21.1) (25 $\mathrm{U} \mathrm{mL}^{-1}$ ), porcine pancreatic $\alpha$ amylase (EC 3.2.1.1) (200 $\mathrm{U} \mathrm{mL}^{-1}$ ), porcine pancreatic lipase (EC 3.1.1.3) (2000 $\mathrm{U} \mathrm{mL}^{-1}$ ) and porcine pancreatic colipase (2:1 colipase to lipase molar excess, equivalent to a mass ratio of roughly $1: 2$ co-lipase to lipase as the mass of human pancreatic lipase is $51.2 \mathrm{kDa}$ and the mass of human co-lipase is 10 $\mathrm{kDa}$ ). Bile salts are added to give a final concentration of $10 \mathrm{mM}$ in the final mixture. There are two options for bile; in both cases the concentration of bile salts needs to be determined, (see assay in Enzyme assays section): bile extract such as B8631 (porcine) or B3883 (bovine) from Sigma-Aldrich or fresh (frozen) porcine bile. $\mathrm{CaCl}_{2}$ is added to reach $0.3 \mathrm{mM}$ in the final digestion mixture. It is recommended to assay the $\mathrm{Ca}^{2+}$ content in pancreatin, if used, and take this into account when adding $\mathrm{Ca}^{2+}$ to the digestive mixture. The $\mathrm{pH}$ may need re-adjustment before finally adding water to the mixture to dilute the stock solution of SIF. The recommended time of intestinal digestion is 2 hours at $37^{\circ} \mathrm{C}$. The $\mathrm{pH}$ may need re-adjustment during digestion. This can be achieved either manually or by automated laboratory titrator.

In a typical example, $20 \mathrm{~mL}$ of gastric chyme is mixed with 11 $\mathrm{mL}$ of SIF electrolyte stock solution, $5.0 \mathrm{~mL}$ of a pancreatin solution $800 \mathrm{U} \mathrm{mL}^{-1}$ made up in SIF electrolyte stock solution based on trypsin activity (pancreatin from porcine pancreas, Sigma), $2.5 \mathrm{~mL}$ fresh bile (160 mM in fresh bile), $40 \mu \mathrm{L}$ of $0.3 \mathrm{M}$ $\mathrm{CaCl}_{2}, 0.15 \mathrm{~mL}$ of $1 \mathrm{M} \mathrm{NaOH}$ to reach $\mathrm{pH} 7.0$ and $1.31 \mathrm{~mL}$ of water. It is recommended to verify the $\mathrm{pH}$ and determine the amount of $\mathrm{NaOH}-\mathrm{HCl}$ required in a test experiment prior digestion, hence base-acid can be added more rapidly and followed by verification of the $\mathrm{pH}$.

\section{Sampling during digestion}

Sample conservation depends on the study focus (food structure, bioaccessibility, enzymatic digestion product etc.), and should be carefully considered for each study. It may be advisable to have individual sample tubes for each time point rather than withdrawing samples from the reaction vessel. Here are some recommendations to inhibit or slow down further enzymatic action on the food sample:

(i) Snap freezing of samples is recommended in liquid nitrogen immediately after the reaction for further analysis. (ii) If samples are sent to other labs, i.e. by courier or by post, the digestion has to be stopped completely; the following procedures are recommended: (a) neutralization of $\mathrm{pH}$ in the gastric phase by adding $0.5 \mathrm{M}$ sodium bicarbonate before snap-freezing in liquid nitrogen and subsequent freeze drying of the samples or (b) addition of protease inhibitor (e.g. $1 \mathrm{mM}$ 4-(2-aminoethyl) benzenesulfonyl fluoride hydrochloride [AEBSF], Roche or similar), snap freezing in liquid nitrogen and subsequent freeze drying of samples.

\section{In vitro digestion parameters - recommendation and justification}

\section{Oral phase}

Mastication and duration of oral phase. In the oral cavity the texture of solid food is significantly altered by mastication and salivation. The food is wetted and lubricated by salivary secretion resulting in a cohesive bolus that is ready for swallowing. Mastication is a complex process that is influenced by a number of factors like food composition, food volume, number of chewing cycles, bite force, teeth condition, degree of hunger and habits. ${ }^{31-34}$ This all affects size, surface area and shape of food particles. $^{35}$ A prediction of particle sizes and particle numbers resulting from mastication that is based on toughness and Young's modulus of food particles can be obtained using the Food Fragmentation Index. ${ }^{35}$ The particle-size distribution of the bolus depends largely on food type. Peyron et al. ${ }^{36}$ and others compared the boluses produced after mastication of raw vegetables (carrot, radish, and cauliflower) and nuts (peanut, almond, and pistachio). Raw vegetables were transformed into similar boluses made up of particles larger than $2 \mathrm{~mm}$, and nuts gave similar boluses containing $90 \%$ of particles smaller than 2 $\mathrm{mm}$. In general, particle sizes of less than $2 \mathrm{~mm}$ are accepted for swallowing unless larger food particles are soft enough to be swallowed. ${ }^{36,37}$ In consideration of the highly individual chewing time and the complex situation of food breakdown during mastication we recommend standardizing the size of solid food particles by using a commercial mincer commonly used in kitchens. Versantvoort et al. ${ }^{6}$ recommended an oral digestion time of 5 minutes in order to ensure proper mechanical action for static models. However, chewing time in vivo is generally much shorter. Therefore, a simulated oral phase of $2 \mathrm{~min}$, i.e. the contact time with enzyme, is recommended in this model. This is somewhat longer than in vivo, however, accuracy and reproducibility in a lab situation may be compromised if using any shorter digestion time. In case of liquid food the simulation of an oral phase may be included, especially if the meal contains starch. However, most liquids do not require an oral phase, mainly due to the very short residence times in the oral cavity.

Volume of salivary secretions. Salivary secretion is also of influence on parameters of the liquid phase of food like $\mathrm{pH}$ value, surface tension and viscosity. Human saliva is a watery complex fluid, which is mainly produced by the parotid, the sublingual and the submandibular glands. The total amount of saliva produced per day is in the range of 1 to $1.5 \mathrm{~L}^{38,39}$ Saliva is excreted at different rates in the stimulated and unstimulated states. The stimulated salivary flow that is contributing to food 
digestion is a hypo-osmotic (110-220 mOsmol kg $\left.{ }^{-1}\right)$ fluid. ${ }^{40-42}$ In addition to $99.5 \%$ of water, human saliva contains $0.3 \%$ of proteins as well as various electrolytes like sodium, potassium, calcium, magnesium, phosphate and bicarbonate. Further components are glucose and nitrogenous products as urea. The main proteins are immunoglobulin A (IgA), $\alpha$-amylase (ptyalin), lysozyme, lactoferrin, as well as mucosal glycoproteins (mucins). ${ }^{38}$ In order to simulate the wetting and lubrication of solid food masses by salivation we recommend that at least $50 \%$ $(\mathrm{w} / \mathrm{v})$ of simulated salivary fluid (SSF) is added to solid food masses prior to the homogenization process. The amount of SSF should be high enough to achieve a paste-like consistency, similar to that of tomato paste or mustard. The best lubricating components of saliva are mucins that are excreted from minor salivary glands. Mucins have the properties of low solubility, high viscosity, high elasticity, and strong adhesiveness. Mastication, speech, and swallowing all are aided by the lubricating effects of mucins. ${ }^{43}$ Versantvoort et al. ${ }^{6}$ and Sarkar et al. ${ }^{44}$ both referred the use of 0.005 and $3 \%(\mathrm{w} / \mathrm{v})$ mucin, respectively. The main objective of the simulation is to help the formation of the bolus that is largely held together by capillary force and allow a solution for the addition of amylase; mucin is not required for either of these. Besides, mucin is only a minor component of saliva thus it was not used in this standardized digestion method.

Amylase activity and pH. Salivary $\alpha$-amylase (ptyalin) has a $\mathrm{pH}$ optimum at $\mathrm{pH} 6.8 .^{42}$ Its activity is generally limited to the mouth cavity and early gastric digestion when the $\mathrm{pH}$ can be high enough due to the buffering capacity of food. $\alpha$-Amylase is inactivated by the acid milieu and the proteolytic activity in the stomach. It is therefore often regarded to be of lesser significance compared to the pancreatic $\alpha$-amylase. ${ }^{45}$ However, it has also been reported that even during 20 to $30 \mathrm{~s}$ of oral food processing, $50 \%$ of the starch in bread and $25 \%$ of the starch in spaghetti can already be hydrolysed. ${ }^{46}$ Recent studies have shown that $\alpha$-amylase plays an important role in the in vitro breakdown kinetics of bread boluses, ${ }^{47}$ and between 25 and $50 \%$ of the starch in bread and pasta boluses was hydrolysed by salivary $\alpha$-amylase in vivo. ${ }^{46}$ While a small portion of starch is hydrolysed by the enzyme $\alpha$-amylase due to the short retention time, almost no protein or fat digestion occurs in the mouth. Therefore we recommend a 2 min incubation, which may include mastication at the same time, see above, with a final concentration of $75 \mathrm{U} \mathrm{mL}^{-1}$ of $\alpha$-amylase in the mixture of food and SSF in case of the presence of carbohydrates that are digestible by $\alpha$-amylase. After oral processing solid food is emptied from the oral cavity typically in at least two swallows for each bite. ${ }^{48}$ Oesophageal passage is a short process with transit times of a few seconds. ${ }^{49}$ No effect on food digestion has been reported.

\section{Gastric phase}

The primary purpose of the stomach is to deliver digesta to the duodenum in a regulated manner to optimize intestinal digestion. In the lower part of the stomach (antrum), the meal is mixed and digested with secreted enzymes and hydrochloric acid, ground by antral movements, and gradually emptied into the duodenum. The significance of physiological and simulated gastric parameters will be discussed.

Duration of gastric step. Gastric emptying of a western type solid meal is usually completed between 3 and $4 h .^{50-52}$ An initial lag phase may be observed before the linear decrease in gastric content. ${ }^{53,54}$ Homogenization of the solid meal usually leads to a one-hour reduction of the length of gastric digestion. ${ }^{55}$ By contrast, liquid meal digestion is characterized by an exponential emptying course with rapid onset of emptying. Emptying of $300 \mathrm{~mL}$ of water requires $1 \mathrm{~h}$ (ref. 56) whereas other studies on liquids with a low protein concentration has shown even shorter transit time $(0.5 \mathrm{~h}) .{ }^{56}$ The addition of nutrients (proteins, lipids or carbohydrates) to a liquid meal also affects the transit time..$^{57,58}$ In addition, the inter- and even intra-individual day to day variations in gastric secretion affects $\mathrm{pH}$ and the rate of gastric emptying. ${ }^{59}$ A simplified static model cannot reproduce the dynamic and transient nature of the in vivo digestion process and the food is exposed to gastric conditions reached at approximately half-gastric emptying time. The $\mathrm{pH}$ is relatively low from the start of the digestion process, without the initial buffering effect of the food. Similarly, the food is exposed to an enzyme-substrate ratio, which is normally only reached at half-gastric emptying time. The conditions of the digestion protocol we recommend need to be applicable to a broad range of meals, therefore we recommend a time of two hours for gastric digestion. This time represents the half emptying of a moderately nutritious and semi-solid meal.

Volume of gastric secretions. The total volume of gastric secretion depends on fasted and fed state of humans and the consistency of the meal. A liquid meal will usually require from half to one volume of gastric secretion for digestion. ${ }^{\mathbf{6 0 6 1}} \mathrm{By}$ contrast, two volumes of gastric juices are secreted for a solid meal. ${ }^{5,60}$ The secretion during the first hour represents half of the total secreted volume for both the liquid and solid meals, even though a continuous emptying will occur that is not possible to simulate by in vitro static digestion. It is thus advised to use one volume of simulated gastric juice for one volume of oral content whatever the meal physical state.

pH. After food intake, $\mathrm{pH}$ usually increases to 5 and above because of the buffering capacity of a typical western-type diet, ${ }^{51,62}$ enriched in vegetable purees ${ }^{52}$ or a cocoa beverage. ${ }^{63}$ The secretion of hydrochloric acid lowers the $\mathrm{pH}$ to the values required for optimal enzyme activities. Consequently, $\mathrm{pH}$ slowly returns to fasted $\mathrm{pH}$ which is commonly found below $2 .^{64}$ Slightly acidic conditions with $\mathrm{pH}$ ranging from 4 to 6 are required for optimal gastric lipase activity ${ }^{64}$ while pepsin will be mainly active between $\mathrm{pH} 2$ and 4 . In order to match the 2 hour recommendation for the length of the gastric simulation the $\mathrm{pH}$ we recommend must represent a mean value for a general meal as described above over the two hours suggested. Thus we recommend the use of a static value of $\mathrm{pH} 3$.

Pepsin activity. Pepsin is the only proteolytic enzyme in the human stomach, however, many isoforms exist. The pepsin content in the stomach varies with individuals, however, mainly increases upon digestion from 0.26 (30 min) to $0.58 \mathrm{mg} \mathrm{mL}$ $(180 \mathrm{~min}){ }^{62}$ Large variations in pepsin activities are reported in 
the literature, partly due to the use of different assays and calculations. ${ }^{65-67}$ Our aim is to produce a standardised procedure and for this purpose pepsin activity is assayed using haemoglobin $(\mathrm{Hb})$ as a substrate, see ESI, $\dagger$ where one unit will produce a $\Delta A_{280}$ of 0.001 per minute at $\mathrm{pH} 2.0$ and $37^{\circ} \mathrm{C}$, measured as TCA-soluble products, also referred to as "Sigma" or "Anson" pepsin units. ${ }^{68,69} \mathrm{~A}$ high homology between human and porcine pepsins (84\%) and the low cost of porcine pepsin from gastric mucosa support a regular use of porcine pepsin in static in vitro digestion models. ${ }^{70}$ Based on an evaluation of values given in the literature ${ }^{65-67}$ we suggest that porcine pepsin is used at $2000 \mathrm{U} \mathrm{mL}^{-1}$ final digestion mixture (equivalent to $4000 \mathrm{U} \mathrm{mL}^{-1}$ in secretion).

Gastric lipase activity. Lipase activity is markedly lower in the gastric compartment (10-120 $\mathrm{U} \mathrm{mL}^{-1}$ ) compared to that in the duodenal tract $\left(80-7000 \mathrm{U} \mathrm{mL}^{-1}\right){ }^{71,72}$ Gastric lipolysis is only partial (5-40\%) mainly because of the lower amounts of enzyme present and its $\mathrm{pH}$ activity profile. ${ }^{71}$ In the absence of triacylglycerols or when the digestion of proteins and polysaccharides is the main focus of the study, the addition of lipase in the gastric step of digestion can be omitted. Human gastric lipase or alternatives with similar characteristics are commercially unavailable at this time and alternatives such as fungal lipases $^{73,74}$ exhibit different activities and specificities. ${ }^{75}$ For these reasons, gastric lipase is not included in the protocol at this time.

Bile salts. Low concentrations of bile acids $(0.2 \mathrm{mM})$ may be found in the human fasting gastric fluid ${ }^{28}$ although not in all individuals. The detection of a concomitant pancreatic lipase activity suggested possible duodeno-gastric reflux. ${ }^{76}$ Thus, bile acids in the gastric phase will not be further considered in this protocol.

Phospholipids. Low concentrations of phospholipids are found in the gastric compartment ${ }^{77}$ and these have been shown to affect the rate of protein digestion in the gastric and small intestinal environments. ${ }^{78,79}$ The presence of surface active components such as phospholipids also has a marked effect on the extent of re-emulsification of lipids as it passes through the high shear regions of the pylorus. Therefore in the absence of phospholipids or other low molecular weight surfactants present in the food, $0.17 \mathrm{mM}$ phospholipids in the final gastric solution is recommended to be included in this static model as optional, non-standard gastric conditions.

\section{Small intestine}

Once the food has been through the simulated gastric phase of digestion it is transferred to a simulation of the digestion that occurs in the small intestine. It is reasonable to assume that this part of the simulation should be well mixed. Once again we suggest that the gastric contents should be diluted $50: 50 \mathrm{v} / \mathrm{v}$ with simulated intestinal fluid (SIF) as given in Table 2. There are many variables that have an impact on transit time through the small intestine but we suggest the time of simulated intestinal digestion should be 2 hours. ${ }^{6,7,80}$ After emptying from the gastric compartment chyme is normally neutralised by the secretion of carbonate. Consequently the duodenal $\mathrm{pH}$ is around $\mathrm{pH} 6.5$ depending on such factors as meal type and gastric emptying rate. The $\mathrm{pH}$ then increases slightly over its length to a value of around 7.5 in the distal ileum. Thus, in order to mimic the $\mathrm{pH}$ in the entire passage through the small intestinal phase in static conditions, we recommend using an average value of $7.0^{6,7,62}$ through the addition of SIF and sodium hydroxide.

The most important components of the simulated small intestinal digestion are the pancreatic enzymes and the bile. In both cases we suggest that there are essentially two options offering differences in specificity, ease of use and cost of each experiment. For the enzymes we recommend either individual enzymes or porcine pancreatin and for bile we recommend the use of either bile extract or frozen porcine bile. There are some guiding principles that should be considered when deciding what approach to use. In the case of the bile, if the proposed experiment involves accurately following lipid hydrolysis in detail then frozen porcine bile should be used, otherwise the bile extract should suffice. The same argument could be used for the use of individual enzymes in that for a detailed analysis of lipid hydrolysis individual enzymes should be used or indeed if the system contains only protein, lipid or starch then the use of only proteases, lipases or amylase respectively may be appropriate. However, the cost and availability of enzymes should also be considered. In both cases the selection of the amount to use in a static model is difficult to assess as physiological measurements refer more to secretion rates rather than specific amounts.

Pancreatin. Porcine pancreatin is readily available and contains all the important pancreatic enzymes in differing amounts. However, as our aim is to produce a standardised procedure we must base the amount added on the activity of a specific enzyme and for this purpose, trypsin is the most appropriate. Thus we recommend that either $4 \times$ USP (U.S. Pharmacopeia) or $8 \times$ USP pancreatin is used and its trypsin activity assayed using the $p$-toluene-sulfonyl-L-arginine methyl ester (TAME) assay. ${ }^{81}$ The amount of pancreatin added should then be based on the trypsin assay and should be sufficient to provide 100 TAME units per $\mathrm{mL}$ of intestinal phase content. The proteolytic, lipolytic and amylolytic activity of the pancreatin should also be determined. In addition, pancreatin also contains significant amounts of various salts and given the importance of the $\mathrm{Ca}^{2+}$ concentration in SIF we suggest that this is also assayed and taken into account when adding calcium to the SIF. It is important to recognise that the concentration of lipase and amylase in the pancreatin will differ from those recommended below and thus for high fat foods this approach may not be appropriate.

Individual enzymes. The alternative to using pancreatin is to use individual enzymes but then which enzymes should be included and how much activity should be used? The primary proteolytic enzymes in the lumen of the small intestine are trypsin and chymotrypsin. Based on an evaluation of values given in the literature we suggest that porcine trypsin is used at $100 \mathrm{U} \mathrm{mL}^{-1}$ final concentration. ${ }^{80}$ The activity is in TAME units where one unit hydrolyses $1 \mu \mathrm{mol}$ of $p$-toluene-sulfonyl-L-arginine methyl ester (TAME) per minute at $25{ }^{\circ} \mathrm{C}, \mathrm{pH} 8.1$, in the 
presence of $10 \mathrm{mM}$ calcium ions. ${ }^{82}$ The equivalence between TAME and BAEE units is: 1 TAME $\mu \mathrm{M}$ unit $=55$ BAEE $A_{253}$ units or 100 TAME $U=5560$ BAEE units. Chymotrypsin should be used at $25 \mathrm{U} \mathrm{mL}^{-1}$ final concentration. ${ }^{83}$ The chymotrypsin activity is in $N$-benzoyl-L-tyrosine ethyl ester (BTEE) units where one unit will hydrolyse $1.0 \mu \mathrm{mol}$ of BTEE per minute at pH 7.8 at $25{ }^{\circ} \mathrm{C} .{ }^{84}$ The ratio of chymotrypsin to trypsin is based on the work of Goldberg et al., who showed that the mass ratio of the two enzymes in human duodenal aspirates averaged about $2: 1$ trypsin to chymotrypsin and this corresponds to a $4: 1$ activity ratio. This is based on the activity of trypsin being 135 TAME $\mathrm{U} \mathrm{mg}^{-1}$ and the activity of chymotrypsin being 64 BTEE $\mathrm{U} \mathrm{mg}^{-1}$. The main carbohydrate hydrolysing agent is pancreatic amylase that should be added at $200 \mathrm{U} \mathrm{mL}^{-1}$ final concentration $^{85}$ where one unit will liberate $1.0 \mathrm{mg}$ of maltose from corn starch in $3 \mathrm{~min}$ at $\mathrm{pH} 6.9$ at $20{ }^{\circ} \mathrm{C} .{ }^{86}$ The most difficult enzymes to accurately quantify in terms of activity are the lipases. We recommend using porcine pancreatic lipase at $2000 \mathrm{U} \mathrm{mL}^{-1}$ (ref. 87) where 1 unit will release $1 \mu \mathrm{mol}$ of free fatty acid per minute from a substrate of tributyrin at $37^{\circ} \mathrm{C}, \mathrm{pH}$ 8.0 , in the presence of $2 \mathrm{mM}$ calcium ions and $4 \mathrm{mM}$ sodium taurodeoxycholate and excess colipase. This amount is based on the mean detection of $0.25 \mathrm{mg} \mathrm{mL}^{-1}$ pancreatic lipase in duodenal aspirates and the activity of the pure enzyme being $8000 \mathrm{U} \mathrm{mg}{ }^{-1}$. The assay should be conducted according to the recommendations of Carrière and coworkers, ${ }^{\mathbf{8 8 , 8 9}}$ also available at the CNRS website (http://eipl.cnrsmrs.fr/assay.php?module=voir\&id=1). In the presence of bile, the rate of lipolysis is significantly improved by the presence of co-lipase, which facilitates the binding of the lipase to the substrate. The co-lipase binds to the lipase in order to enable the lipase to adsorb to the oil-water interface. Thus, it is important to ensure that the co-lipase is added in a $2: 1$ molar excess with the lipase. This is equivalent to a mass ratio of roughly $1: 2$ co-lipase-lipase as the mass of the similar human pancreatic lipase is $51.2 \mathrm{kDa}$ and the mass of human co-lipase is $10 \mathrm{kDa}$. Commercially available pancreatin usually contains enough colipase for maximum lipase activity, which can be verified, if necessary, by adding additional colipase in the course of the lipase assay and record changes in lipase activity.

Bile. Bile is important for the transport of the products of lipolysis and in the adult intestine the typical concentration in the fed state is $10 \mathrm{mM}$ final concentration in total fluid. ${ }^{62}$ As discussed above, we suggest two options for sources of bile for the intestinal stage, which are either to use a porcine or bovine bile extract ${ }^{90}$ or frozen porcine bile, which is easily extracted from the porcine gall bladder. In either case the concentration of bile salts will need to be determined so that in the SIF the concentration is made up to $20 \mathrm{mM}$, resulting in a concentration of $10 \mathrm{mM}$ in the final digestion mixture. There are a number of different commercial kits available for the determination of bile that are mostly based on similar methods ${ }^{\mathbf{1 1}}$ (e.g. the bile assay kit 122129990313 from Diagnostic Systems GmbH in Germany) that can give a bile concentration in $\mu \mathrm{M}$.

\section{Suitability of static digestion models}

In vitro digestion studies are widely used with the aim of predicting the behaviour of food components in the digestive tract. Most of these studies are performed in static models where gastric and small intestinal digestion is mimicked in two consecutive steps. During each step, the substrate is incubated for a specific time with simulated gastric and small intestinal digestive fluids, respectively. The $\mathrm{pH}$ is generally maintained at a fixed value by using a $\mathrm{pH}$-stat or a buffer. This approach allows methods that are relatively simple to perform and permit high throughput testing. However, the simplicity of static models narrows the range of applicability, which drives the need for adapting a previously described method for a specific research question. This, and the lack of consensus on relevant physiological conditions, has led to a proliferation of different methods. In our consortium we aim to harmonize in vitro systems that simulate digestive processes by defining key parameters and conditions that need to be included to study a specific food or substrate and to measure a specific endpoint. As a starting point, we present in this paper a protocol with a set of standard conditions to be used in a simple static model. These standard conditions are based on relevant in vivo data and supported by rationale and source of data. This discussion focuses on the use and limitation of such a simple static model in relation to mimicking in vivo conditions.

\section{Static models in relation to in vivo conditions}

General aspects. The digestive tract is a complex system that aims to provide the body with optimal nutrition and energy. Therefore, feedback systems regulate every step of digestion. The feedback response may differ individually e.g. based on age, physical constitution (status of the body) and habits. This results in both food and individual dependent variation of aspects such as chewing, gastric emptying, secretion of digestive fluids and gastro-intestinal transit times. An in vitro digestive system does not include the complex interaction between food and body, which is often regarded as the major drawback of in vitro simulations. Whether or not this really is a drawback depends on the research question. Control over individual parameter in mechanistic studies for product optimization allows the effects of variation in product composition to be studied under the same conditions. In addition, accurately controlled conditions do not give the high variability often encountered with in vivo studies, thus limiting the need for large numbers of replicates to obtain sufficient statistical power.

Oral step. Chewing and the consequent particle size reduction is a major determinant of the digestion of solid food. However, the consistency of chewed food, both in terms of particle size and hydration-lubrication with saliva varies widely depending on the type of food and the individual. The use of a food mincer standardizes the particle size and homogeneity of the food bolus but does not include the interaction between food and chewing on the digestion. Static models are not able to mix highly viscous food-saliva boluses as might be swallowed in 
vivo. Thus, the food needs to be mixed with artificial saliva to obtain a sufficient liquid input for mixing in the gastric step.

Gastric step. The function of the stomach is to prepare and gradually deliver the meal to the small intestine in order to optimize further digestion in the small intestine. The meal is stored in the upper part of the stomach and gradually transferred to the lower part where the chyme is mixed and ground until particles are small enough to pass the pylorus. Homogeneity of the gastric content in vivo is generally low. The low level of motility in the upper part of the stomach causes solid ingested boluses to stack on top of each other and more liquid gastric content to phase separate. ${ }^{92-94}$ Gastric emptying occurs gradually, strongly determined by the caloric value of the nutrients that enter the duodenum. ${ }^{95}$ During the gastric phase, the meal is diluted by gastric juice containing enzymes and hydrochloric acid. Pepsin, gastric lipase and swallowed salivary amylase, have their optimum $\mathrm{pH}$ at 2.5, 5.4 and 6.8, respectively. ${ }^{42,96,97}$ In the fasting state, the $\mathrm{pH}$ in the stomach is around 2 or below. During ingestion of the meal, the $\mathrm{pH}$ increases depending on the buffer capacity of the meal. After that, the $\mathrm{pH}$ is gradually decreasing due to hydrochloric acid secretion. The slow penetration of acid in a solid food bolus results in a prolonged high $\mathrm{pH}$ in the interior of the bolus. This all implies that during gastric emptying different fractions of the meal are exposed to different $\mathrm{pH}$ values and enzyme activities.

Static models use a relatively dilute digestive mixture that is well homogenised using a stirrer, shaker or impeller. Although this does not reflect the mixing of gastric content in vivo, it exposes all substrates to the set point $\mathrm{pH}$ and related enzyme activities, and allows representative samples to be taken.

The complete meal with simulated gastric digestive fluid is exposed to a fixed $\mathrm{pH}$ during a fixed period. Generally the gastric $\mathrm{pH}$ is maintained around 2, which may be the right value for the fasting state but does not reflect the $\mathrm{pH}$ after intake of a meal. Whether or not a static gastric digestion is adequate depends on the effect of each physiological parameter on the digestion and intended endpoint. In some cases a gastric step could even be omitted since the gastric digestion is completely overruled by the small intestinal digestion. On the other hand, the omission of gastric lipase during the gastric step, as chosen here, might not be fully adequate for mimicking the complete process of gastrointestinal lipolysis as for example preliminary digestion of dietary triglycerides by gastric lipase is known to further trigger pancreatic lipase activity on lecithin-stabilized emulsions in vitro. ${ }^{98}$ In other cases incubation at $\mathrm{pH} 2$ during 1 hour might lead to a complete peptic digestion, while this is not the case during a much milder exposure in vivo.

Small intestinal step. In the duodenum, the chyme that is gradually emptied from the stomach is neutralized with bicarbonate and mixed with bile and pancreatic juice. Bile is primarily important to emulsify fat and to form mixed micelles that solubilise and transport lipophilic products to the gut wall for absorption. During transit of approximately 3 hours through the small intestine, substrates and enzyme to substrate ratios are changing due to the digestion and absorption of digestive products and water. The major drawback of small intestinal static models is that they do not include removal of digestive products during the digestion process, which may cause product inhibition of enzymes. This is generally overcome by using non physiological low substrate concentrations in a dilute system.

\section{Use and validation of static models}

As with all models, digestive models are a simplification of reality and should be as simple as possible. However, as Albert Einstein stated, "we should make things as simple as possible, but not simpler". This also applies to designing model systems to study the behaviour of compounds in the gastro-intestinal tract. A digestion model should include all relevant parameters to predict the endpoint intended. The more relevant the parameters included are, the wider the applicability but also the higher the complexity.

An accurate prediction of the in vivo bio-accessibility (availability for absorption through the gut wall) is limited since static models lack the simulation of realistic enzyme substrate ratios, $\mathrm{pH}$ profiles, transit times and removal of digested products, in time and place. Ranking of the digestion of different products is more feasible, provided that the set conditions are adequate for the variation in characteristics of the products. Static models might also be appropriate for mechanistic studies, where the digestion of a substrate under specific conditions is aimed for. The matrix composition of the different products should not differ too much and should be limited in complexity. In other words, static models are useful to study the digestion of single substrates or simple meals under specific conditions.

In addition to the limitations caused by the applied conditions, the assessment of digestion is strongly affected by the analysis of the digested fraction. The fraction of product released should be adequately separated from the undigested fraction. A centrifugation step will only separate insoluble undigested material with sufficient density. Undigested compounds might also be colloidal dispersions. Therefore, ultra-filtration or dialysis may be the better choice. Analysing free glucose, amino acids or fatty acids to determine the digestibility of macro-nutrients is not appropriate, since the pancreatic digestion is not complete. Therefore an additional step with brush border enzymes such as amylo-glucosidase or peptidase is required to complete starch and protein digestion, respectively. Analysis of lipid digestion in a static model is generally performed in a $\mathrm{pH}$ stat where the produced fatty acids are assumed to be equivalent to the amount of neutralizing alkali. Product inhibition can be overcome by continuous addition of $\mathrm{Ca}^{2+}$ ions to precipitate free fatty acids as calcium soaps. ${ }^{99}$

In contrast to the more holistic dynamic models that should be validated for their ability to reproduce the conditions in the gut, a static model should be validated against their intended use. In this paper we have described a protocol with conditions and composition of digestive fluids that have a broad consensus in terms of physiological relevance. This protocol will be tested and validated by different research groups for a variety of applications to determine its use and limitations. This process 
will lead to the establishment of key parameters and settings for specific applications and endpoints. This allows model systems to be adapted and validated for specific applications and endpoints by choosing the physiological relevant parameters that have consensus in a big scientific community. This might lead to also using more complex systems but we should "make things as simple as possible, but not simpler".

\section{Acknowledgements}

COST action FA1005 Infogest ${ }^{22}$ (http://www.cost-infogest.eu/) is acknowledged for providing funding for travel, meetings and conferences. The many other researchers, mostly associated to the above COST action, which have contributed to the discussion on digestion parameters are also acknowledged.

\section{References}

1 M. Minekus, PhD thesis, University of Utrecht, The Netherlands, 1998.

2 M. Wickham, R. Faulks and C. Mills, Mol. Nutr. Food Res., 2009, 53, 952-958.

3 O. Ménard, T. Cattenoz, H. Guillemin, I. Souchon, A. Deglaire, D. Dupont and D. Picque, Food Chem., 2014, 145, 1039-1045.

4 S. J. Hur, B. O. Lim, E. A. Decker and D. J. McClements, Food Chem., 2011, 125, 1-12.

5 A. M. Kaukonen, B. J. Boyd, W. N. Charman and C. J. Porter, Pharm. Res., 2004, 21, 254-260.

6 C. H. Versantvoort, A. G. Oomen, E. Van de Kamp, C. J. Rompelberg and A. J. Sips, Food Chem. Toxicol., 2005, 43, 31-40.

7 K. A. Kopf-Bolanz, F. Schwander, M. Gijs, G. Vergères, R. Portmann and L. Egger, J. Nutr., 2012, 142, 245-250.

8 J. Maldonado-Valderrama, A. P. Gunning, P. J. Wilde and V. J. Morris, Soft Matter, 2010, 6, 4908-4915.

9 J. Hasjim, G. C. Lavau, M. J. Gidley and R. G. Gilbert, Biomacromolecules, 2010, 11, 3600-3608.

10 K. Larsson, L. Cavonius, M. Alminger and I. Undeland, J. Agric. Food Chem., 2012, 60, 7556-7564.

11 B. Lorrain, O. Dangles, M. Loonis, M. Armand and C. Dufour, J. Agric. Food Chem., 2012, 60, 9074-9081.

12 D. D. Miller, B. R. Schricker, R. R. Rasmussen and D. Van Campen, Am. J. Clin. Nutr., 1981, 34, 2248-2256.

13 E. Biehler and T. Bohn, Curr. Nutr. Food Sci., 2010, 6, 44-69. 14 L. Tavares, I. Figueira, G. J. McDougall, H. L. Vieira, D. Stewart, P. M. Alves, R. B. Ferreira and C. N. Santos, Eur. J. Nutr., 2013, 52, 225-236.

15 J. Bouayed, L. Hoffmann and T. Bohn, Food Chem., 2011, 128, 14-21.

16 C. Vors, P. Capolino, C. Guerin, E. Meugnier, S. Pesenti, M.-A. Chauvin, J. Monteil, N. Peretti, M. Cansell, F. Carriere and M.-C. Michalski, Food Funct., 2012, 3, 537546.

17 H. D. Williams, M. U. Anby, P. Sassene, K. Kleberg, J.-C. Bakala-N'Goma, M. Calderone, V. Jannin, A. Igonin, A. Partheil, D. Marchaud, E. Jule, J. Vertommen, M. Maio,
R. Blundell, H. Benameur, F. Carrière, A. Müllertz, C. W. Pouton and C. J. H. Porter, Mol. Pharm., 2012, 9, 3286-3300.

18 H. D. Williams, P. Sassene, K. Kleberg, J.-C. Bakala-N'Goma, M. Calderone, V. Jannin, A. Igonin, A. Partheil, D. Marchaud, E. Jule, J. Vertommen, M. Maio, R. Blundell, H. Benameur, F. Carrière, A. Müllertz, C. J. H. Porter and C. W. Pouton, J. Pharm. Sci., 2012, 101, 3360-3380.

19 D. J. McClements and Y. Li, Food Funct., 2010, 1, 32-59.

20 E. Biehler, L. Hoffmann, E. Krause and T. Bohn, J. Nutr., 2011, 141, 1769-1776.

21 E. Reboul, M. Richelle, E. Perrot, C. Desmoulins-Malezet, V. Pirisi and P. Borel, J. Agric. Food Chem., 2006, 54, 87498755.

22 D. Dupont, A. Bordoni, A. Brodkorb, F. Capozzi, T. Cirkovic Velickovic, M. Corredig, P. Cotter, I. De Noni, C. Gaudichon, M. Golding, T. Lea, I. Le Huërou-Luron, A. Mackie, C. Madsen, B. De Meulenaer, Y. Nys, A. Pihlanto, I. Recio, D. Rémond, T. Requena, I. Souchon, D. Swiatecka, S. Turgeon, G. Vegarud, R. Vreeburg, W. Weitschies and M. Wickham, Food Dig., 2011, 2, 23-25.

23 S. Lindquist and O. Hernell, Curr. Opin. Clin. Nutr. Metab. Care, 2010, 13, 314-320.

24 M. Grassi, L. Petraccia, G. Mennuni, M. Fontana, A. Scarno, S. Sabetta and A. Fraioli, Nutr. Hosp., 2011, 26, 659-668.

25 C. Bourlieu, O. Ménard, K. Bouzerzour, G. Mandalari, A. Macierzanka, A. R. Mackie and D. Dupont, Crit. Rev. Food Sci. Nutr., 2013, 1427-1457.

26 M. Jakob, Normalwerte pocket, Börm Bruckmeier Verlag, 2008.

27 C. Lentner, Geigy Scientific tables. Vol. 1, Units of measurement, body fluids, composition of the body, nutrition, Ciba-Geigy Basel, Switzerland, 1981.

28 A. Lindahl, A.-L. Ungell, L. Knutson and H. Lennernäs, Pharm. Res., 1997, 14, 497-502.

29 M. J. Riddell, J. A. Strong and D. Cameron, Exp. Physiol., 1960, 45, 1-11.

30 P. Anderson, M. Hector and M. Rampersad, Int. J. Paediatr. Dent., 2001, 11, 266-273.

31 F. Fontijn-Tekamp, A. Slagter, A. Van Der Bilt, M. V. T. Hof, D. Witter, W. Kalk and J. Jansen, J. Dent. Res., 2000, 79, 15191524.

32 L. Engelen, A. Fontijn-Tekamp and A. v. d. Bilt, Arch. Oral Biol., 2005, 50, 739-746.

33 P. Lucas, R. Ow, G. Ritchie, C. Chew and S. Keng, J. Dent. Res., 1986, 65, 400-404.

34 E. Helkimo, G. E. Carlsson and M. Helkimo, Acta Odontol. Scand., 1978, 36, 33-41.

35 K. R. Agrawal, P. W. Lucas, J. F. Prinz and I. C. Bruce, Arch. Oral Biol., 1997, 42, 1-9.

36 M.-A. Peyron, A. Mishellany and A. Woda, J. Dent. Res., 2004, 83, 578-582.

37 M.-L. Jalabert-Malbos, A. Mishellany-Dutour, A. Woda and M.-A. Peyron, Food Quality and Preference, 2007, 18, 803812.

38 S. P. Humphrey and R. T. Williamson, J. Prosthet. Dent., 2001, 85, 162-169. 
39 P. D. V. de Almeida, A. Gregio, M. Machado, A. De Lima and L. R. Azevedo, J. Contemp. Dent. Pract., 2008, 9, 72-80.

40 M. B. D. Gaviao, L. Engelen and A. Van Der Bilt, Eur. J. Oral Sci., 2004, 112, 19-24.

41 L. Engelen, R. A. de Wijk, J. F. Prinz, A. van der Bilt and F. Bosman, Physiol. Behav., 2003, 78, 165-169.

42 A. Pedersen, A. Bardow, S. B. Jensen and B. Nauntofte, Oral Dis., 2002, 8, 117-129.

43 L. A. Tabak, Crit. Rev. Oral Biol. Med., 1990, 1, 229-234.

44 A. Sarkar, K. K. Goh and H. Singh, Food Hydrocolloids, 2009, 23, 1270-1278.

45 G. A. van Aken, M. H. Vingerhoeds and E. H. de Hoog, Curr. Opin. Colloid Interface Sci., 2007, 12, 251-262.

46 C. Hoebler, A. Karinthi, M. Devaux, F. Guillon, D. Gallant, B. Bouchet, C. Melegari and J. Barry, Br. J. Nutr., 1998, 80, 429-436.

47 G. M. Bornhorst, H. Hivert and R. P. Singh, LWT-Food Sci. Technol., 2014, 55, 27-33.

48 A. Okada, M. Honma, S. Nomura and Y. Yamada, Physiol. Behav., 2007, 90, 172-179.

49 H. N. Nguyen, J. Silny, D. Albers, E. Roeb, C. Gartung, G. Rau and S. Matern, Am. J. Physiol.: Gastrointest. Liver Physiol., 1997, 273, G958-G964.

50 J. D. Gardner, A. A. Ciociola and M. Robinson, J. Appl. Physiol., 2002, 92, 427-434.

51 J. B. Dressman, R. R. Berardi, L. C. Dermentzoglou, T. L. Russell, S. P. Schmaltz, J. L. Barnett and K. M. Jarvenpaa, Pharm. Res., 1990, 7, 756-761.

52 V. Tyssandier, E. Reboul, J.-F. Dumas, C. Bouteloup-Demange, M. Armand, J. Marcand, M. Sallas and P. Borel, Am. J. Physiol.: Gastrointest. Liver Physiol., 2003, 284, G913-G923.

53 D. D. Burton, H. J. Kim, M. Camilleri, D. A. Stephens, B. P. Mullan, M. K. O'Connor and N. J. Talley, Am. J. Physiol.: Gastrointest. Liver Physiol., 2005, 289, G261-G266.

54 J. R. Malagelada, G. F. Longstreth, W. H. Summerskill and V. L. Go, Gastroenterology, 1976, 70, 203-210.

55 J. R. Malagelada, V. L. W. Go and W. H. J. Summerskill, Dig. Dis. Sci., 1979, 24, 101-110.

56 H. C. Lin, C. Prather, R. S. Fisher, J. H. Meyer, R. W. Summers, M. Pimentel, R. W. Mccallum and V. Loening-Baucke, Dig. Dis. Sci., 2005, 50, 989-1004.

57 O. Goetze, A. Steingoetter, D. Menne, I. R. van der Voort, M. A. Kwiatek, P. Boesiger, D. Weishaupt, M. Thumshirn, M. Fried and W. Schwizer, Am. J. Physiol.: Gastrointest. Liver Physiol., 2007, 292, G11-G17.

58 L. Marciani, P. A. Gowland, R. C. Spiller, P. Manoj, R. J. Moore, P. Young and A. J. Fillery-Travis, Am. J. Physiol.: Gastrointest. Liver Physiol., 2001, 280, G1227-G1233.

59 F. Carrière, C. Renou, E. Ville, P. Grandval and R. Laugier, Digestion, 2001, 64, 46-53.

60 J.-R. Malagelada, V. W. Go and W. H. J. Summerskill, Dig. Dis. Sci., 1979, 24, 101-110.

61 O. Wisén and C. Johansson, Metabolism, 1992, 41, 390-395. 62 L. Kalantzi, K. Goumas, V. Kalioras, B. Abrahamsson, J. B. Dressman and C. Reppas, Pharm. Res., 2006, 23, 165-176.

63 L. Y. Rios, R. N. Bennett, S. A. Lazarus, C. Rémésy, A. Scalbert and G. Williamson, Am. J. Clin. Nutr., 2002, 76, 1106-1110.
64 F. Carrière, H. Moreau, V. Raphel, R. Laugier, C. Benicourt, J. L. Junien and R. Verger, Eur. J. Biochem., 1991, 202, 75-83.

65 E. K. Ulleberg, I. Comi, H. Holm, E. B. Herud, M. Jacobsen and G. E. Vegarud, Food Dig., 2011, 2, 52-61.

66 M. Armand, M. Hamosh, J. S. DiPalma, J. Gallagher, S. B. Benjamin, J. R. Philpott, D. Lairon and P. Hamosh, Am. J. Clin. Nutr., 1995, 62, 74-80.

67 J. DiPalma, C. L. Kirk, M. Hamosh, A. R. Colon, S. B. Benjamin and P. Hamosh, Gastroenterology, 1991, 101, 116-121.

68 M. L. Anson and A. E. Mirsky, J. Gen. Physiol., 1932, 16, 59-63.

69 M. L. Anson, J. Gen. Physiol., 1938, 22, 79-89.

70 M. Fujinaga, M. M. Chernaia, S. C. Mosimann, M. N. James and N. I. Tarasova, Protein Sci., 1995, 4, 960-972.

71 M. Armand, Curr. Opin. Clin. Nutr. Metab. Care, 2007, 10, 156-164.

72 F. Carrière, P. Grandval, C. Renou, A. Palomba, F. Priéri, J. Giallo, F. Henniges, S. Sander-Struckmeier and R. Laugier, Clin. Gastroenterol. Hepatol., 2005, 3, 28-38.

73 S. Blanquet-Diot, M. Soufi, M. Rambeau, E. Rock and M. Alric, J. Nutr., 2009, 139, 876-883.

74 G. A. van Aken, E. Bomhof, F. D. Zoet, M. Verbeek and A. Oosterveld, Food Hydrocolloids, 2011, 25, 781-788.

75 P. L. Zentler-Munro, B. A. Assoufi, K. Balasubramanian, S. Cornell, D. Benoliel, T. C. Northfield and M. E. Hodson, Pancreas, 1992, 7, 311-319.

76 M. Armand, P. Borel, B. Pasquier, C. Dubois, M. Senft, M. Andre, J. Peyrot, J. Salducci and D. Lairon, Am. J. Physiol.: Gastrointest. Liver Physiol., 1996, 271, G172G183.

77 J. Wenner, T. Gunnarsson, H. Graffner and G. Lindell, Dig. Dis. Sci., 2000, 45, 1648-1652.

78 G. Mandalari, A. M. Mackie, N. M. Rigby, M. S. J. Wickham and E. N. C. Mills, Mol. Nutr. Food Res., 2009, 53, S131-S139.

79 A. Macierzanka, A. I. Sancho, E. N. C. Mills, N. M. Rigby and A. R. Mackie, Soft Matter, 2009, 5, 538-550.

80 E. L. McConnell, H. M. Fadda and A. W. Basit, Int. J. Pharm., 2008, 364, 213-226.

81 A. Vandermeers, M.-C. Vandermeers-Piret, J. Rathé and J. Christophe, Clin. Chem., 1972, 18, 1514-1517.

82 K. A. Walsh and P. E. Wilcox, in Methods Enzymol., ed. L. L. Gertrude and E. Perlmann, Academic Press, 1970, vol. 19, pp. 31-41.

83 D. M. Goldberg and K. G. Wormsley, Gut, 1970, 11, 859-866. 84 H. U. Bergmeyer, K. Gawehn, D. H. Williamson and P. Lund, Methods of Enzymatic Analysis: Vol. 1, Academic Press, 1974. 85 J. Keller and P. Layer, Gut, 2005, 54, 1-28.

86 P. Bernfeld, in Methods Enzymol., Academic Press, 1955, vol. 1, pp. 149-158.

87 F. Carrière, C. Renou, V. Lopez, J. De Caro, F. Ferrato, H. Lengsfeld, A. De Caro, R. Laugier and R. Verger, Gastroenterology, 2000, 119, 949-960.

88 Y. Gargouri, L. Sarda, G. Pieroni, C. Riviere, P. Lowe, F. Ferrato and R. Verger, in Enzymes of lipid metabolism II, Springer, 1986, pp. 19-22.

89 F. Carrière, J. Barrowman, R. Verger and R. Laugier, Gastroenterology, 1993, 105, 876-888. 
90 P. Capolino, C. Guérin, J. Paume, J. Giallo, J.-M. Ballester, J.-F. Cavalier and F. Carrière, Food Dig., 2011, 2, 43-51.

91 B. J. Collins, P. Watt, T. O'Reilly, R. J. McFarland and A. H. Love, J. Clin. Pathol., 1984, 37, 313-316.

92 K. Schulze, Neurogastroenterol. Motil., 2006, 18, 172-183.

93 L. Marciani, M. S. J. Wickham, D. Bush, R. Faulks, J. Wright, A. J. Fillery-Travis, R. C. Spiller and P. A. Gowland, Br. J. Nutr., 2006, 95, 331-339.

$94 \mathrm{~W}$. Schwizer, A. Steingoetter and M. Fox, Scand. J. Gastroenterol., 2006, 41, 1245-1260.
95 J. A. Calbet and D. A. MacLean, J. Physiol., 1997, 498, 553559.

96 D. W. Piper and B. H. Fenton, Gut, 1965, 6, 506-508.

97 M. Hamosh, H. L. Klaeveman, R. O. Wolf and R. O. Scow, J. Clin. Invest., 1975, 55, 908.

98 Y. Gargouri, G. Pieroni, C. Rivière, P. A. Lowe, J.-F. Saunière, L. Sarda and R. Verger, Biochim. Biophys. Acta, Lipids Lipid Metab, 1986, 879, 419-423.

99 N. H. Zangenberg, A. Müllertz, H. Gjelstrup Kristensen and L. Hovgaard, Eur. J. Pharm. Sci., 2001, 14, 237-244. 